\title{
Upgrading Waste Heat from a Cement Plant for Thermochemical Hydrogen Production
}

\author{
A. Odukoya ${ }^{{ }^{*}}$ and G. F. Naterer ${ }^{2}$ \\ ${ }^{1,2}$ Memorial University of Newfoundland, St. John’s, Newfoundland, Canada
}

\begin{abstract}
A calcium oxide/steam chemical heat pump (CHP) is presented in the study as a means to upgrade waste heat from industrial processes for thermochemical hydrogen production. The CHP is used to upgrade waste heat for the decomposition of copper oxychloride $\left(\mathrm{CuO} \cdot \mathrm{CuCl}_{2}\right)$ in a copper-chlorine $(\mathrm{Cu}-\mathrm{Cl})$ thermochemical cycle. A formulation is presented for high temperature steam electrolysis and thermochemical splitting of water using waste heat of a cement plant. Numerical models are presented for verifying the availability of energy for potential waste heat upgrading in cement plants. The optimal hydration and decomposition temperatures for the calcium oxide/steam reversible reaction of $485 \mathrm{~K}$ and $565 \mathrm{~K}$ respectively are obtained for the combined heat pump and thermochemical cycle. The coefficient of performance and overall efficiency of 4.6 and $47.8 \%$ respectively are presented and discussed for the CHP and hydrogen production from the cement plant.
\end{abstract}

\section{Nomenclature}

$E_{o} \quad$ reversible cell potential (V)

E cell voltage (V)

$1^{1 *}$ Corresponding Author: Research Project Engineer, Faculty of Engineering and Applied Science, Memorial University, St. John's, Newfoundland, 240 Prince Phillip Drive, St. John's, NL Canada A1B 3X5, Email: aodukoya@mun.ca, Phone:1-709-864-2395, Fax: (709) 864-8975

${ }^{2}$ Dean and Professor, Faculty of Engineering and Applied Science, Memorial University, St. John's, Newfoundland, 240 Prince Phillip Drive, St. John's, NL Canada A1B 3X5 


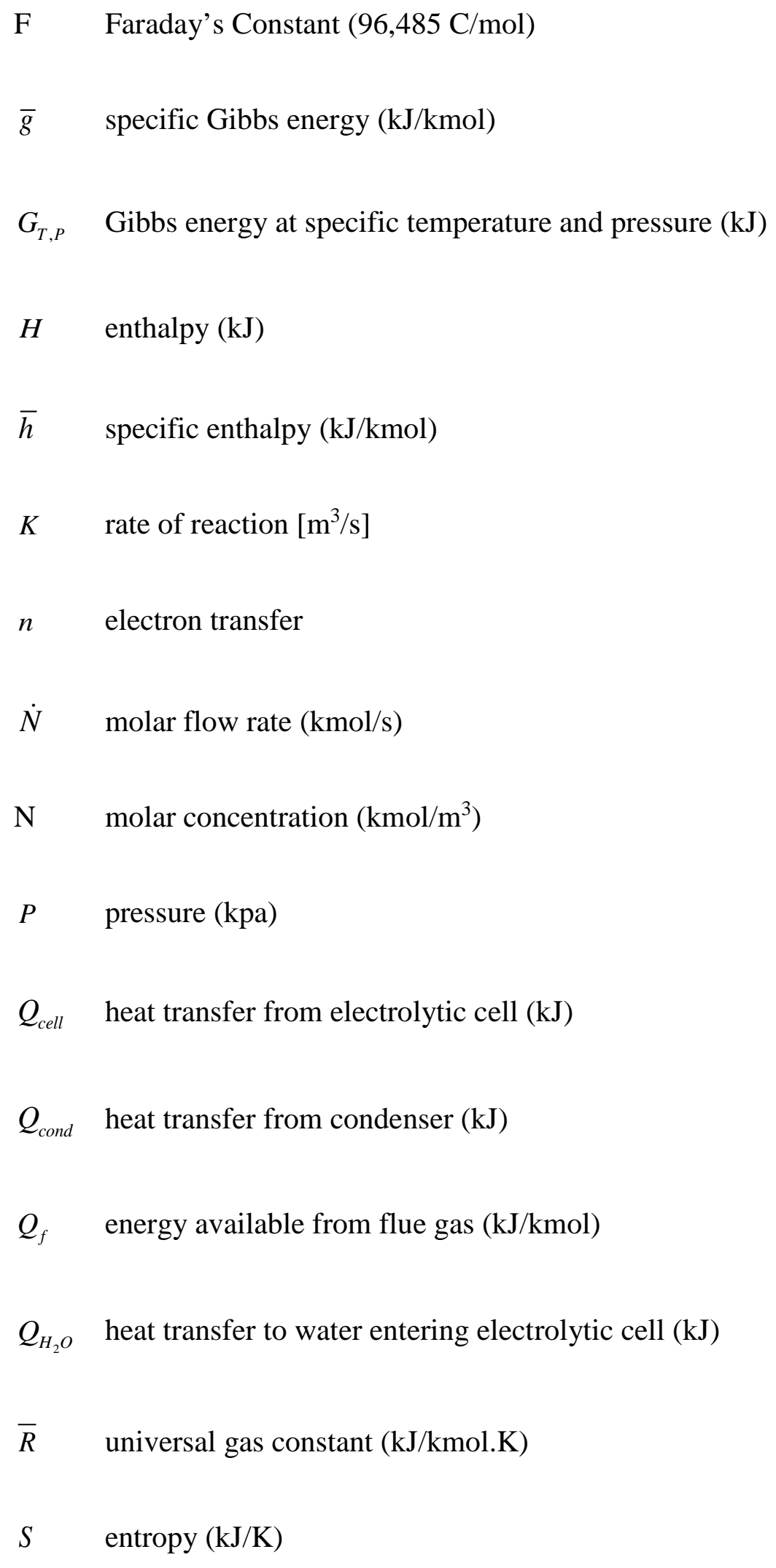


$S_{g e n} \quad$ entropy generation $(\mathrm{kJ} / \mathrm{K})$

$T \quad$ temperature $(\mathrm{K})$

V volume $\left(\mathrm{m}^{3}\right)$

$W_{\text {gen }} \quad$ steam cycle work output $(\mathrm{kJ})$

$W_{\text {pump }}$ pump work $(\mathrm{kJ})$

\section{Greek}

$\eta_{E} \quad$ efficiency of electrolytic hydrogen production

$\eta_{p} \quad$ overall plant efficiency

$\mu_{k} \quad$ chemical potential

\section{Subscripts}

d decomposition

E electrolytic cell

evap evaporator

$f \quad$ flue gas

o environment

s surface

\section{Abbreviations}


CHP chemical heat pump

COP coefficient of performance

LHV lower heating value $[\mathrm{kJ} / \mathrm{mol}]$

\section{Introduction}

Waste heat from energy intensive industrial processes such as cement and steel plants can be effectively utilized by other thermal processes to reduce energy losses and increase the system efficiency. Effective waste heat utilization depends on a combination of thermoeconomic analysis and needs of the industrial processes. This study specifically investigates the utilization of waste heat from cement plants. A waste heat case study of a cement plant in Bowmanville, Ontario, Canada is examined for this study of thermochemical production of hydrogen.

Several studies have investigated the commercial viability of the copper-chlorine $(\mathrm{Cu}-\mathrm{Cl})$ cycle [1-7]. An efficiency of about $45 \%$ has been reported when combined with Generation IV nuclear power plants [8]. Steam methane reforming is the most common commercial method of producing hydrogen, while high temperature steam electrolysis is another alternative. Hydrogen is required as a feedstock in many applications such as the oil sands industry, pharmaceutical, biochemical and food industries. The use of hydrogen as a fuel can significantly reduce the greenhouse gas emissions of industrial processes. This paper studies the use of hydrogen as a fuel in the cement plant to reduce the overall greenhouse gas emissions from the plant and increase the overall efficiency of its operation.

Electrolysis is a commercial technology to produce hydrogen. When the overall efficiency of a system including the generation of electricity is considered, this efficiency typically becomes 18 to $24 \%$ [9]. Thermochemical splitting of water is an emerging technology and promising 
alternative to electrolysis of water. Two of the thermochemical cycles are the sulphur-iodine (S-I) and copper-chlorine (Cu-Cl) cycles. The $\mathrm{Cu}-\mathrm{Cl}$ cycle (up to $550^{\circ} \mathrm{C}$ ) requires lower temperature heat input to produce hydrogen than the S-I cycle (up to $825-900^{\circ} \mathrm{C}$ ) $[10,11]$. Although the reduced temperature is advantageous, materials to handle the highly corrosive $\mathrm{HCl}$ at high temperatures is a challenge. Naterer et al. [8] have demonstrated a large-scale $\mathrm{Cu}-\mathrm{Cl}$ cycle at the University of Ontario Institute of Technology (UOIT). Brown et al. [11] have studied the S-I cycle. Past studies have shown the viability of using waste heat from high temperature industrial applications to supply the heat required by the $\mathrm{Cu}-\mathrm{Cl}$ cycle [8]

This paper combines the thermochemical cycle presented by Naterer et al. [8] to a cement plant using a calcium oxide/steam $\left(\mathrm{CaO} / \mathrm{H}_{2} \mathrm{O}\right)$ chemical heat pump (CHP). The precalciner $\left(340^{\circ} \mathrm{C}\right)$ and the kiln $\left(1067^{\circ} \mathrm{C}\right)$ of a cement plant produce high temperature flue gas. This paper investigates a $\mathrm{CaO} / \mathrm{H}_{2} \mathrm{O}$ CHP to upgrade the flue gas from the cement plant to provide the heat required by a $\mathrm{Cu}-\mathrm{Cl}$ plant for the decomposition of copper oxychloride $\left(\mathrm{CuO} \cdot \mathrm{CuCl}_{2}\right)$ when the flue gas temperature is $340^{\circ} \mathrm{C}$. This flue gas is typically not recycled in the plant and it is sent directly through the stack. The heat pump is used to upgrade the flue gas from the cement plant to a temperature required in the oxygen decomposition reactor. The higher temperature $\left(1067^{\circ} \mathrm{C}\right)$ available from the kiln is normally recirculated within the cement plant to improve the efficiency of the cement plant. Fig. 1 shows a schematic of the proposed system when combined with the oxygen reactor in the $\mathrm{Cu}-\mathrm{Cl}$ cycle. Zamfirescu et al. [12, 13] proposed a system of vapour compression of $\mathrm{CuCl}_{2}$ to upgrade waste heat for thermochemical hydrogen production.

CHPs are investigated for heat upgrading in this study due to their high storage capacity and heat of reaction. Several working pairs were investigated by Wongsuwan et al. [14], who outlined the preferred combination for the appropriate working conditions. Ogura and Mujumdar 
[15] proposed a CHP which produces hot dry air for an industrial drying process based on $\mathrm{CaO}$ hydration and decarbonization of $\mathrm{CaCO}_{3}$. The system had a $\mathrm{COP}$ of about 1.52 with an output temperature of about $550^{\circ} \mathrm{C}$. Fujimoto [16] extended the work of Ogura et al. [17, 18] experimentally and numerically for a smaller system with an output temperature of about $400^{\circ} \mathrm{C}$.

Naterer [19] also investigated the second law viability of upgrading waste heat for thermochemical hydrogen production using a magnesium oxide/vapor CHP. The results showed that the COP increased with a higher evaporator temperature. The Carnot cycle for both cooling and heating were also reported and compared analytically. Although a maximum COP of about 2.75 was reported for the CHP, this paper will show that higher COPs are achievable by replacing components in a $\mathrm{CaO} / \mathrm{H}_{2} \mathrm{O}$ cycle. Sharonov and Aristov [20] compared the thermodynamic performance of chemical heat pumps and adsorption heat pumps for non-regenerative cycles. The results indicated that the Carnot efficiency can be obtained for mono-variant equilibrium gas-solid reactions but cannot be applied to di-variant equilibrium systems. Kato et al. [21-23] also investigated a high temperature heat pump using a combination of $\mathrm{CaO} / \mathrm{CO}_{2}$ and $\mathrm{PbO} / \mathrm{CO}_{2}$. A temperature of about $860^{\circ} \mathrm{C}$ was achieved experimentally and optimal kinetics of the reactions is presented. The possibility of lead poisoning makes the system less attractive for commercialization.

The $\mathrm{CaO} / \mathrm{H}_{2} \mathrm{O}$ CHP is well suited for thermochemical production of hydrogen since $\mathrm{Ca}(\mathrm{OH})_{2}$ can be produced from limestone used to produced cement. This will reduce the possibility of contamination within the cement plant and also enhance possible integration. This paper analytically investigates a combined system using a pinch analysis and chemical energy balance of the reacting mixture. The effects of temperature and pressure of the flue gas from the cement plant on the operation are analyzed. The hydration and evaporator pressure of the heat 
pump are also varied to achieve the optimal plant operating condition. The proposed system is compared with a system using flue gas to produce hydrogen via electrolysis and also electricity from a steam power plant.

\section{System Description}

Various cycle configurations have been proposed for thermochemical hydrogen production using the $\mathrm{Cu}-\mathrm{Cl}$ cycle and between three to five major chemical reactions [8, 24]. The four-step cycle has been chosen as the preferred cycle because it avoids the problem associated with transporting solid copper particles. The chemical reactions for the four-step cycle are outlined in Table 1. The cycle configuration for the four-step process is shown in Fig. 2.

The CHP is used to provide the heat required by the oxygen decomposition reactor as shown in Fig. 3. The heat upgrading of the flue gas from the cement plant is achieved by the hydration of $\mathrm{CaO}$. The exothermic reaction of $\mathrm{CaO}$ and water vapor results in a high temperature $\mathrm{Ca}(\mathrm{OH})_{2}$. The extent of the reaction depends on the reaction coefficient, which is determined by the temperature and pressure of the reaction. The hydration reaction is given as follows:

$$
\mathrm{CaO}+\mathrm{H}_{2} \mathrm{O} \rightleftharpoons \mathrm{Ca}(\mathrm{OH})_{2}
$$

The upgraded heat is passed through a heat exchanger to the oxygen decomposition reactor in the hydrogen production cycle. The cooled $\mathrm{Ca}(\mathrm{OH})_{2}$ is then fed into the dehydration/decomposition reactor, where $\mathrm{CaO}$ and $\mathrm{H}_{2} \mathrm{O}$ are formed in the reverse reaction (from right to left) at a different temperature but at the same pressure. This reaction is endothermic and achieved by supplying the hot flue gas from the cement plant to form the desired products ( $\mathrm{CaO}$ and vapor). The experimental setup by Fujimoto [16] used tubular reactors to achieve the reaction. The vapor is throttled to the condenser pressure, where it is cooled to the saturation temperature 
by the pressurized liquid flowing into the hydration reactor. The liquid water is collected and pumped to the pressure of the hydration reactor. The circulation of steam in the reactors can be achieved in batches or operated continuously. This analysis assumes that two reactors are used for continuous operation of the plant. The steam/liquid flows are cycled between both reactors. The high pressure liquid is then passed into a heat exchanger where steam from the decomposition reactor is used to produce steam at the required temperature for the hydration reaction.

The following section establishes mass, energy and chemical exergy balances to determine the optimal operating conditions of the system. The temperature and pressure of the hydration and decomposition reaction are determined by a thermodynamic analysis. The temperature and flow rate from existing cement plants are used in the analysis.

\section{Chemical Heat Pump}

A parametric analysis of the combined system is performed to determine the applicability of the CHP for the thermochemical production of hydrogen using the $\mathrm{Cu}-\mathrm{Cl}$ cycle. Optimal parameters are determined for the plant's operation. An energy analysis of each component and the interaction between different modules are considered in modeling the cycle performance. The system is designed to produce $\mathrm{Ca}(\mathrm{OH})_{2}$ between $550^{\circ} \mathrm{C}$ and $590^{\circ} \mathrm{C}$. The molar flow rates and inlet temperature of the reactants in the hydrolysis reactor ( $\mathrm{CaO}$ and vapor) are determined analytically. The Gibbs relation is used to determine the chemical exergy of the reaction in Eq. (1).

In order for the reaction to proceed in the preferred direction, the following relation of molar flow rate, reaction potential, and entropy generation must be satisfied.

$$
\partial S_{g e n}=\sum \mu_{k} \frac{\partial N_{k}}{T}>0
$$


where $\mu$ is the chemical potential of the species, $\mathrm{N}$ is the molar concentration, and $\mathrm{T}$ is the temperature of the reaction. This can be related to the change in Gibbs energy as follows:

$d G=-S d T+V d P-T d S_{g e n}$

where $\mathrm{P}$ is pressure, $\mathrm{S}$ is the entropy of the mixture and $\mathrm{V}$ is the volume of the mixture. At specified values of T, P and molar flow rate, the change in Gibbs energy can be expressed as:

$d G_{T, P}=\sum \mu_{k} d N_{k}=-T d S_{g e n} \leq 0$

For the decomposition/hydration reaction, the change in Gibbs energy is used to determine availability and direction of the reaction in Eq. (1). This can be expressed as:

$\dot{N}_{\mathrm{Ca}(\mathrm{OH})_{2}} \bar{g}_{\mathrm{Ca}(\mathrm{OH})_{2}}=\left(\dot{N}_{\mathrm{CaO}} \bar{g}_{\mathrm{CaO}}+\dot{N}_{\mathrm{H}_{2} \mathrm{O}} \bar{g}_{\mathrm{H}_{2} \mathrm{O}}\right)$

where $g$ is the specific Gibbs energy. This can also be expressed as $h_{k}-T_{k} S_{k}$ for each of the chemically reacting species.

The change in enthalpy of the reaction in Eq. (1) is used to determine the inlet temperature of $\mathrm{CaO}$ and $\mathrm{H}_{2} \mathrm{O}_{(\mathrm{g})}$. Earlier studies by Ogura [18] reported an optimal pressure for the reaction in Eq. (1) for an exit temperature of $500^{\circ} \mathrm{C}$. The rate of the reactions was determined experimentally by Fujimoto et al. [16]. The rate of the reactions for the hydration and decomposition can be expressed as:

$$
\begin{aligned}
& K_{1}=5 \cdot \exp \left(\frac{18.305-3816.443}{T-46.13}\right) \\
& K_{2}=\frac{875 \times \exp \left(-4.81 \times 10^{4} / \bar{R} T\right)}{1+51.1 \times \exp \left(-1.1096 \times 10^{4} / \bar{R} T\right)}
\end{aligned}
$$


where $K_{1}$ is the reaction rate for the decomposition reaction and $K_{2}$ is the reaction rate for the hydration reaction. The reaction rates are based on a first order reaction for particle diameters of $0.7-1 \mathrm{~mm}$. These rates are used to determine the concentration of the solid particles in the decomposition and hydration reactions.

A pinch point analysis is used to determine the exit temperature of $\mathrm{Ca}(\mathrm{OH})_{2}$ from the oxygen decomposition reactor. The chemical decomposition from the $\mathrm{CuO}^{-\mathrm{CuCl}_{2}}$ reactor is expressed as:

$\mathrm{Cu}_{2} \mathrm{OCl}_{2(s)} \rightarrow 2 \mathrm{CuCl}(l)+1 / 2 \mathrm{O}_{2(g)}$

The heat required for the reaction to proceed was determined by Lewis [9] as $285 \mathrm{~kJ} / \mathrm{molH}_{2}$. The energy balance for the oxygen decomposition reactor is expressed as:

$\dot{N}_{\mathrm{H}_{2}} \cdot \Delta H_{\mathrm{CuO} . \mathrm{CuCl} \mathrm{C}_{2}}=\dot{N}_{\mathrm{Ca}(\mathrm{OH})_{2}} \cdot\left(H_{\mathrm{Ca}(\mathrm{OH})_{2}}^{\text {in }}-\mathrm{H}_{\mathrm{Ca}(\mathrm{OH})_{2}}^{\text {out }}\right)$

where $\dot{N}_{\mathrm{H}_{2}}$ is the molar flow rate of hydrogen. The $\mathrm{CuCl}_{2}$ and oxygen $\left(\mathrm{O}_{2}\right)$ exit the oxygen decomposition reactor at about $450^{\circ} \mathrm{C}$. Assuming a pinch point of $10^{\circ} \mathrm{C}$, the molar flow rate of $\mathrm{Ca}(\mathrm{OH})_{2}$ can be determined for the required temperature for the reactor operation. The oxygen from the reactor is used to preheat the steam in the $\mathrm{Cu}-\mathrm{Cl}$ cycle. The cooled $\mathrm{Ca}(\mathrm{OH})_{2}$ is sent into the decomposition reactor. The flue gas from the cement plant is used as heat input for the decomposition reaction. This is achieved at the same pressure of the hydration reaction but at a lower temperature,

$\left.\dot{N}_{f} \cdot Q_{f}+\dot{N}_{\mathrm{Ca}(\mathrm{OH})_{2}} \bar{g}_{\mathrm{Ca} a \overline{\mathrm{O}}\left(\mathrm{f} f \mathrm{~N}_{2} \mathrm{CaO}\right.} \bar{g}_{\mathrm{CaO}}+\dot{N}_{\mathrm{H}_{2} \mathrm{O}} \overline{\mathrm{g}}_{\mathrm{H}_{2} \mathrm{O}}\right)$ 
where $Q_{f}$ is the available energy from the cement plant and $\dot{N}_{f}$ is the molar flow rate of the flue gas. The temperature of the flue gas from the cement plant will determine the reaction temperature. The numerical predictions assume that the temperature of the exit steam will be the final temperature of the decomposition reaction. The steam is throttled to the evaporator pressure, where it is used to generate steam for the hydrolysis reaction. The heat transferred to the steam for the hydrolysis reaction can be expressed as:

$Q_{\text {cond }}=\dot{N}_{H_{2} \mathrm{O}} \cdot\left(\bar{h}_{d}-\bar{h}_{\text {evap }}\right)$

where $\bar{h}_{d}$ is the enthalpy of the steam leaving the decomposition reactor and $\bar{h}_{\text {evap }}$ is the enthalpy of the liquid at the evaporator saturation temperature. The numerical model assumes $30 \%$ of the available heat is lost to the surroundings in the heat exchangers. After determining the interdependence of each state point, the performance of the system can be estimated by taking into account extraneous heat losses to the surrounding. The coefficient of performance of the heat pump can be expressed as:

$\mathrm{COP}=\frac{\dot{N}_{\mathrm{H}_{2}} \cdot \Delta H_{\text {CuO.CuCl }}}{\dot{N}_{f} Q_{f}+W_{\text {pump }}}$

where $W_{\text {pump }}$ is the pump work. The overall efficiency of the combined system becomes:

$\eta_{p}=\frac{\dot{N}_{H_{2}} L H V_{H_{2}}}{\dot{N}_{f} Q_{f}+W_{\text {pump }}}$

where $\mathrm{LHV}_{\mathrm{H}_{2}}$ is the lower heating value of hydrogen $(241.83 \mathrm{~kJ} / \mathrm{mol})$. Numerical simulations are performed to determine the thermodynamic parameters to achieve the decomposition of 
$\mathrm{CuO} . \mathrm{CuCl}_{2}$ in the $\mathrm{Cu}-\mathrm{Cl}$ cycle. The waste heat from the process is recycled within the $\mathrm{Cu}-\mathrm{Cl}$ cycle. An audit of the recirculation of heat within the system has been reported in past studies [8].

\section{Rankine Steam Power Plant}

A Rankine steam power plant operating within the same pressure range as the heat pump is investigated to determine the overall efficiency of a system used to produce electrical power. The system is also compared with electricity generation from a steam cycle used to produce hydrogen via steam electrolysis. The electrochemical work for the separation of high pressure steam using electrolysis is estimated by the change in Gibbs energy $\left(\Delta G=-n F E^{\circ}\right)$. The reversible

cell potential is determined by the Nernst equation $\left(E=E_{o}-2.303 \cdot\left(\frac{\bar{R} T}{n F}\right) \ln (K)\right)$. The overall efficiency of the combined steam cycle and combined electrolytic cycle is determined by:

$$
\begin{gathered}
\eta_{\text {steam }}=\frac{W_{\text {gen }}-W_{\text {pump }}}{\dot{N}_{f} Q_{f}} \\
\eta_{E}=\frac{\dot{N}_{\mathrm{H}_{2}} L H V_{\mathrm{H}_{2}}}{\dot{N}_{f} Q_{f}+Q_{\mathrm{H}_{2} \mathrm{O}}}
\end{gathered}
$$

where $\eta_{\text {steam }}$ and $\eta_{E}$ are the efficiencies of the steam cycle to produce electricity and the efficiency of the cycle to produce both electricity and hydrogen respectively. The waste heat from the electrolytic cell can be used in a variety of ways to increase the efficiency of the electrolytic cell as reported by Zang et al. [25]. The results show that the maximum efficiency is achieved when excess heat is used to preheat the steam in the electrolysis cell. The resulting efficiency of the system is estimated as: 


$$
\eta_{E}=\frac{\dot{N}_{\mathrm{H}_{2}} L H V_{\mathrm{H}_{2}}}{\dot{N}_{f} Q_{f}+Q_{\text {cell }}\left(1-\frac{T_{o}}{T_{s}}\right)+Q_{\mathrm{H}_{2} \mathrm{O}}\left(1-\frac{T_{o}}{T_{s}}\right)}
$$

The performance of the CHP, steam cycle and electrolysis are compared in the following section by examining waste heat utilization for hydrogen production.

\section{Results and Discussion}

The numerical model is used to determine the performance of the heat upgrade via the CHP for thermochemical hydrogen production, using the flue gas available from the preclinker at $340^{\circ} \mathrm{C}$. The study further examines the output efficiency if the waste heat at $1,067^{\circ} \mathrm{C}$ from the clinker is used directly in the $\mathrm{CuO}^{-\mathrm{CuCl}_{2}}$ decomposition chamber in the $\mathrm{Cu}-\mathrm{Cl}$ cycle. The study also compares the heat used to produce electricity as a power source for high temperature electrolysis to split water to produce hydrogen. The parameters in the numerical modelling for the CHP are highlighted in Table 2. To simplify the model constant pressure was assumed during each sub process. The reactor temperature was assumed to be equivalent to the reaction temperature. The reference environment is assumed to be $25^{\circ} \mathrm{C}$ for the numerical simulation and a reference state for the thermodynamic data for each compound. The cooling water is assumed to be perfectly mixed. A 30\% loss is assumed for the heat exchanger used for the condenser and evaporator.

The simulation is performed with a combination of MATLAB [26] and Engineering Equation Solver (EES) [27]. An initial guess is made for the hydration process temperature. An iterative technique is used to determine the final temperature of the hydrolysis reaction. The result from each hydration process is the input to the oxygen decomposition chamber and the rate of hydrogen production is estimated. A similar iterative procedure is used to determine the exit temperature from the dehydration process. An iterative procedure is performed on the condenser 
to determine the molar flow rate of cooling water required. The cooling water is assumed to be the supply water for the evaporation process. The simulation determines if makeup water is required for complete hydration of $\mathrm{CaO}$.

The decomposition/hydration pressure is varied between 3.67 and 5.07 bar for a fixed inlet temperature into the $\mathrm{Cu}-\mathrm{Cl}$ cycle. The COP varied between 2.5 and 4.6 for the range of pressures. Increasing the decomposition pressure reduces the COP of the cycle for the same temperature of decomposition. The COP of the $\mathrm{CHP} / \mathrm{Cu}-\mathrm{Cl}$ system declines with flow rate as shown in Fig 4 . The reaction kinetics of the $\mathrm{Cu}-\mathrm{Cl}$ cycle limits the flow rate of the $\mathrm{CuOCuCl}_{2}$ through the oxygen decomposition chamber. The temperature required for the reaction can be achieved at lower flow rates and lower flue gas temperatures. The excess thermal energy of the flue gas can be recycled within the system to increase the COP of the combined system. The COP at a flow rate of 3.2kg/s is about $25 \%$ higher than the COP at a mass flow rate of $4.2 \mathrm{~kg} / \mathrm{s}$ for the range of temperatures (591-613 K) considered in this paper. Increasing the flow rate will have no further impact on the production of hydrogen because the stoichiometric combination $\mathrm{CaO} / \mathrm{H}_{2} \mathrm{O}$ reaction is necessary to produce the temperature required by the oxygen decomposition reactor. Higher flow rates of water into the condenser results in an increase in the pump work. The COP achieved is significantly higher than previously reported by Ogura and Mujumdar [15] for a similar CHP for drying. This can be attributed to replacing the compressor in the design with a pump to reduce the work input to the CHP.

The effects of varying mass flow rate on COP for various flue gas temperatures are shown in Fig. 4. The changing temperature does not have a significant effect on the COP when comparing results from Figs. 4 and 5. At a fixed mass flow rate, the maximum change in COP is less than $1 \%$ (Fig. 5). Although the mass flow rate has a more significant effect on the COP, the required 
temperature of the oxygen decomposition reactor is achieved at the lowest temperature of the flue gas. The minimum flow rate of flue gas for the decomposition reaction is numerically estimated as $3.2 \mathrm{~kg} / \mathrm{s}$ based on the pressure range considered in this study.

The effects of evaporator pressure and condenser pressure on COP of the CHP are shown in Fig. 6. The slight change in evaporator pressure has a greater effect on the COP for a fixed flue gas mass flow rate $(3.2 \mathrm{~kg} / \mathrm{s})$ and temperature $\left(318^{\circ} \mathrm{C}\right)$ than the decomposition pressure. The maximum COP will be achieved at the minimum evaporator pressure and minimum decomposition pressure for the range of flue gas properties in this paper. Fig. 6 is used to identify the optimum operating condition for the heat pump. Increasing the decomposition pressure increases the mass flow rate of flow flue gas required to achieve the decomposition of $\mathrm{Ca}(\mathrm{OH})_{2}$. This also increases the decomposition temperature, thereby increasing the heat lost from the decomposition chamber. The excess heat can be recycled in the $\mathrm{Cu}-\mathrm{Cl}$ cycle for heating the steam used in the hydrolysis step of the cycle (Table 1; Step 3).

The results from the studies are compared to past studies by Naterer [19] and Sharonov et al.[20] for a fixed mass flow rate and inlet temperature as shown in Table 3. The COP of the $\mathrm{CHP} / \mathrm{Cu}-\mathrm{Cl}$ cycle is lower than that reported by the previous authors as the derived estimates are based on the Carnot cycle operation of the cycles. The heat generated from the $\mathrm{CaO} / \mathrm{H}_{2} \mathrm{O}$ CHP reaction is much higher than that generated from either the $\mathrm{MgO} / \mathrm{H}_{2} \mathrm{O}$ or salt/ammonia combinations. This would explain why the $\mathrm{COP}$ of the $\mathrm{CHP} / \mathrm{Cu}-\mathrm{Cl}$ cycle in this study is close to data reported in Table 3.

The results show that steam is supplied between $460 \mathrm{~K}$ and $485 \mathrm{~K}$ for the hydration reaction to proceed. The heat upgrade is dependent on the pressure shown in Fig. 6. Increased pressure 
requires the steam to be supplied at higher temperatures. The decomposition reaction results in steam produced between $473 \mathrm{~K}$ and $565 \mathrm{~K}$ for the range of pressures considered. Two reactors will be required for continuous operation of the CHP for thermochemical hydrogen production. Experimental results by Ogura et al. [17] also suggest the use of two reactors for continuous operation.

The hydrogen production capacity for the proposed plant design is about 6.17 tons/day based of the waste heat supplied from the cooling stack for a case study of a cement plant in Bowmanville, Ontario, Canada. When considering the waste heat from the clinker being diverted to produce hydrogen in the $\mathrm{Cu}-\mathrm{Cl}$ cycle, an efficiency of about $47.8 \%$ is achievable from the cycle. The flue gas $\left(1,067^{\circ} \mathrm{C}\right)$ recycled in the preclinker is used as a direct heat source for the oxygen decomposition reactor in the $\mathrm{Cu}-\mathrm{Cl}$ cycle. Fig. 7 shows the effect of mass flow rate of the flue gas on the thermodynamic efficiency when combining the waste heat from the preclinker of the cement plant directly to the oxygen decomposition chamber of the $\mathrm{Cu}-\mathrm{Cl}$ cycle. The lowest mass flow rate produces the highest efficiency since the temperature required for the reaction is $550^{\circ} \mathrm{C}$. Increasing the temperature only increases the heat loss from the heat exchanger used to transfer energy to the decomposition reaction. It is assumed that heat from the heat exchanger can still be recycled to heat the raw material in the cement production line. A minimal flue gas flow rate will achieve the required reaction, and increase the efficiency of the combined system without requiring a heat pump. A thermoeconomic analysis will be required to determine the impact of diverting a portion of the flue gas currently used in the preclinker to produce hydrogen. The calorific value of hydrogen is much higher than the flue gas, hence burning the hydrogen produced in the preclinker might reduce the overall energy requirement for the cement production. This will also reduce the environmental impact of the industrial process. 
The flue gas from the cement plant at $340^{\circ} \mathrm{C}$ can be used in a variety of ways, which include producing process steam, hydrogen, and electricity amongst other industrial applications. These paper focuses on electricity and hydrogen production because cement production is a highly energy intensive process. The hydrogen produced could be used as a fuel to produce the heat required for the kiln process and also preheating of the raw materials. If electricity is produced, it can be used to power auxiliary systems within the plant.

When the flue gas from the cement plant is used to generate electricity in a steam cycle and power the water electrolysis cell. The numerical study presented here uses the flue gas temperature available at $590 \mathrm{~K}$ and $640 \mathrm{~K}$ to model the steam/electrolysis cycle. This is necessary for consistency with other hydrogen production configurations considered in this study. The increase in flue gas temperature results in an increased net work output from the steam cycle. This increases the electrical work supplied to the electrolysis cell. The increase in electrical work to the cell results in a higher capacity to produce more hydrogen using electrolysis. The most hydrogen is produced at the lower pressures using water electrolysis. The effect of varying the pressure from 1.01bar to 3.07bar is only about $4.5 \%$ for the range of flue gas temperatures considered in Fig. 8. The change of hydrogen production beyond 3.07bar is less than $1 \%$ for the range of temperatures considered. The hydrogen production from the combined $\mathrm{CHP} \mathrm{Cu}-\mathrm{Cl}$ cycle (6.017 tons/day) is significantly higher than using the flue gas for the water electrolysis process. The production of hydrogen from the $\mathrm{Cu}-\mathrm{Cl}$ cycle does not vary with flue gas temperature due to the kinetics of the reaction that generates hydrogen.

The steam cycle is modeled using the input condition of the cement plant. The flue gas is assumed to pass through a heat exchanger where it is used to generate superheated steam that is passed into the steam turbine. A pinch point of $10^{\circ} \mathrm{C}$ is assumed when modeling the heat exchanger 
and the exit flue gas temperature is assumed to be about $100^{\circ} \mathrm{C}$. The steam cycle is also assumed to operate between the decomposition and evaporation pressure of the CHP to ensure a reasonable comparison. Increasing the flue gas temperature increases the efficiency of the steam/electrolysis cycle for generating hydrogen, as shown in Fig. 9. The maximum efficiency occurs at the lower pressure of water electrolysis. This provides useful verification of the results in Fig. 8, indicating the rate of hydrogen production from the steam/electrolysis combined system. The steam cycle efficiency is also directly proportional to the increase in flue gas temperature. The combined steam/electrolysis system increases the cycle efficiency by about $16 \%$ for the range of flue gas temperatures considered.

The numerical prediction is validated by comparing the transient temperature distribution of the hydration process of the $\mathrm{CHP} / \mathrm{Cu}-\mathrm{Cl}$ with experimental results reported by Fujimoto et al. [16] (Fig. 10). The trend of the numerical simulation over predicts the start of the hydration process as shown in Fig. 10. This is may be due to the inability to adequately account for heat losses from the reactor chamber and the experimental errors in estimating the rate of the reaction before the equilibrium temperature is attained. The average difference between the predicted and experimental results is about $5.4 \%$. It can be concluded that the results fall within a $90 \%$ confidence interval for the range of temperatures considered.

\section{Conclusions}

The results from this study confirm the viability of using waste heat for thermochemical hydrogen production. A high COP of about 4.6 is achievable at moderate decomposition temperatures and pressures. The optimal decomposition pressure (3.67 bar) and evaporator pressure (0.042 bar) is determined for the range of flue gas temperatures considered. A comparison between high temperature electrolysis and the combined thermochemical splitting of hydrogen shows that a 
higher efficiency is achieved with the CHP. The possibility of also using waste heat from the kiln is examined and a higher efficiency is achieved using the flue gas directly in the thermochemical cycle. The viability of either using waste heat at $340^{\circ} \mathrm{C}$ or a portion at $1067^{\circ} \mathrm{C}$ from the cement plant to produce hydrogen is presented in this study. This model can be extended to other industrial processes to reduce the greenhouse gas emissions from such systems.

\section{Acknowledgements}

Financial support from the Canada Research Chairs program and the Natural Sciences and Engineering Research Council of Canada (NSERC) is gratefully acknowledged. 


\section{$\underline{\text { References }}$}

[1] G.F. Naterer, S. Suppiah, L. Stolberg, M. Lewis, M. Ferrandon, Z. Wang, I. Dincer, K. Gabriel, M.A. Rosen, E. Secnik, E.B. Easton, L. Trevani, I. Pioro, P. Tremaine, S. Lvov, J. Jiang, G. Rizvi, B.M. Ikeda, L. Lu, M. Kaye, W.R. Smith, J. Mostaghimi, P. Spekkens, M. Fowler, J. Avsec, Clean hydrogen production with the $\mathrm{Cu}-\mathrm{Cl}$ cycle-Progress of international consortium, II: Simulations, thermochemical data and materials, Int. J. Hydrogen Energy. 36 (2011) 15486-15501.

[2] G.F. Naterer, S. Suppiah, L. Stolberg, M. Lewis, Z. Wang, I. Dincer, M. Rosen, K. Gabriel, E. Secnik, E. Easton, I. Pioro, S. Lvov, J. Jiang , J. Mostaghimi, B.M. Ikeda, G. Rizvi, L. Lu, A. Odukoya, P. Spekkens, M. Fowler, J. Avsec, Progress of international hydrogen production network for the thermochemical $\mathrm{Cu} — \mathrm{Cl}$ cycle, Int. J. Hydrogen Energy. 38 (2013) 740-759.

[3] G.F. Naterer, S. Suppiah, L. Stolberg, M. Lewis, S. Ahmed, Z. Wang, M. Rosen, I. Dincer, K.

Gabriel, E. Secnik, E.B. Easton, S.N. Lvov, V. Papangelakis, A. Odukoya, Progress of international program on hydrogen production with the copper-chlorine cycle, Int. J. Hydrogen Energy. 39 (2014) 2431-2445.

[4] G.F. Naterer, I. Dincer, C. Zamfirescu, Hybrid Copper-Chlorine Cycle, Hydrogen Production from Nuclear Energy, Springer, 8(2013) 273-438.

[5] G. Naterer, S. Suppiah, M. Lewis, K. Gabriel, I. Dincer, M.A. Rosen, M. Fowler, G. Rizvi, E.B. Easton, B.M. Ikeda, M.H. Kaye, L. Lu, I. Pioro, P. Spekkens, P. Tremaine, J. Mostaghimi, J. Avsec, J. Jiang, Recent Canadian advances in nuclear-based hydrogen production and the thermochemical Cu-Cl cycle, Int. J. Hydrogen Energy. 34 (2009) 2901-2917. 
[6] G.F. Naterer, S. Suppiah, L. Stolberg, M. Lewis, Z. Wang, V. Daggupati, K. Gabriel, I. Dincer, M.A. Rosen, P. Spekkens, S.N. Lvov, M. Fowler, P. Tremaine, J. Mostaghimi, E.B. Easton, L. Trevani, G. Rizvi, B.M. Ikeda, M.H. Kaye, L. Lu, I. Pioro, W.R. Smith, E. Secnik, J. Jiang, J. Avsec, Canada's program on nuclear hydrogen production and the thermochemical $\mathrm{Cu}-\mathrm{Cl}$ cycle, Int. J. Hydrogen Energy. 35 (2010) 10905-10926.

[7] G.F. Naterer, S. Suppiah, L. Stolberg, M. Lewis, M. Ferrandon, Z. Wang, I. Dincer, K. Gabriel, M.A. Rosen, E. Secnik, E.B. Easton, L. Trevani, I. Pioro, P. Tremaine, S. Lvov, J. Jiang, G. Rizvi, B.M. Ikeda, L. Lu, M. Kaye, W.R. Smith, J. Mostaghimi, P. Spekkens, M. Fowler, J. Avsec, Clean hydrogen production with the $\mathrm{Cu}-\mathrm{Cl}$ cycle - Progress of international consortium, I: Experimental unit operations, Int. J. Hydrogen Energy. 36 (2011) 15472-15485.

[8] G. Naterer, S. Suppiah, L. Stolberg, M. Lewis, Z. Wang, I. Dincer, M. Rosen, K. Gabriel, E. Secnik, E. Easton, Progress of international hydrogen production network for the thermochemical Cu-Cl cycle, Int. J. Hydrogen Energy. 38 (2012) 740-759.

[9] M.A. Lewis, J.G. Masin, P.A. O'Hare, Evaluation of alternative thermochemical cycles, Part I: The methodology, Int. J. Hydrogen Energy. 34 (2009) 4115-4124.

[10] L.C. Brown, J. Funk, S. Showalter, Initial screening of thermochemical water-splitting cycles for high efficiency generation of hydrogen fuels using nuclear power, GA-A23373 report. (2000).

[11] L.C. Brown, G.E. Besenbruch, R. Lentsch, K.R. Schultz, J. Funk, P. Pickard, A. Marshall, S. Showalter, High efficiency generation of hydrogen fuels using nuclear power, General Atomics Report GA-A24285. (2003). 
[12] C. Zamfirescu, G. Naterer, I. Dincer, Upgrading of waste heat for combined power and hydrogen production with nuclear reactors, J. Eng. Gas Turb. Power. 132 (2010) 102911-102919.

[13] C. Zamfirescu, G. Naterer, I. Dincer, Vapor compression CuCl heat pump integrated with a thermochemical water splitting cycle, Thermochimica Acta. 512 (2011) 40-48.

[14] W. Wongsuwan, S. Kumar, P. Neveu, F. Meunier, A review of chemical heat pump technology and applications, Appl. Therm. Eng. 21 (2001) 1489-1519.

[15] H. Ogura, A.S. Mujumdar, Proposal for a novel chemical heat pump dryer, Drying Technol. 18 (2000) 1033-1053.

[16] S. Fujimoto, E. Bilgen, H. Ogura, $\mathrm{CaO} / \mathrm{Ca}(\mathrm{OH})_{2}$ chemical heat pump system, Energ. Convers. Manage. 43 (2002) 947-960.

[17] H. Ogura, H. Ishida, R. Yokooji, H. Kage, Y. Matsuno, A.S. Mujumdar, Experimental studies on a novel chemical heat pump dryer using a gas-solid reaction, Drying Technol. 19 (2001) 14611477.

[18] H. Ogura, T. Yamamoto, H. Kage, Y. Matsuno, A.S. Mujumdar, Effects of heat exchange condition on hot air production by a chemical heat pump dryer using $\mathrm{CaO} / \mathrm{H}_{2} \mathrm{O} / \mathrm{Ca}(\mathrm{OH})_{2}$ reaction, Chem. Eng. J. 86 (2002) 3-10.

[19] G.F. Naterer, Second Law viability of upgrading waste heat for thermochemical hydrogen production, Int. J. Hydrogen Energy. 33 (2008) 6037-6045.

[20] V. Sharonov, Y.I. Aristov, Chemical and adsorption heat pumps: Comments on the second law efficiency, Chem. Eng. J. 136 (2008) 419-424. 
[21] Y. Kato, N. Harada, Y. Yoshizawa, Kinetic feasibility of a chemical heat pump for heat utilization of high-temperature processes, Appl. Therm. Eng. 19 (1999) 239-254.

[22] Y. Kato, N. Yamashita, K. Kobayashi, Y. Yoshizawa, Kinetic study of the hydration of magnesium oxide for a chemical heat pump, Appl. Therm. Eng. 16 (1996) 853-862.

[23] Y. Kato, M. Yamada, T. Kanie, Y. Yoshizawa, Calcium oxide/carbon dioxide reactivity in a packed bed reactor of a chemical heat pump for high-temperature gas reactors, Nucl. Eng. Des. 210 (2001) 1-8.

[24] M.F. Orhan, İ Dinçer, M.A. Rosen, Efficiency comparison of various design schemes for copper-chlorine $(\mathrm{Cu}-\mathrm{Cl})$ hydrogen production processes using Aspen Plus software, Energ. Convers. Manage. 63 (2012) 70-86.

[25] H. Zhang, G. Lin, J. Chen, Evaluation and calculation on the efficiency of a water electrolysis system for hydrogen production, Int. J. Hydrogen Energy. 35 (2010) 10851-10858.

[26] Mathworks Inc, MATLAB, R2012a, Version 7.14. 0. 739, (2012).

[27] Klein, S.A., Engineering Equation Solver, EES. Professional Version 9, 213 (2012). 


\begin{tabular}{|c|c|c|c|c|}
\hline Step & Reaction & $\begin{array}{c}\text { Temp. } \\
\text { Range }\left({ }^{\circ} \mathrm{C}\right)\end{array}$ & & $\begin{array}{c}\text { Feed } \\
\text { Output* }\end{array}$ \\
\hline 1 & $\begin{array}{c}2 \mathrm{CuCl}(\mathrm{aq})+2 \mathrm{HCl}(\mathrm{aq}) \rightarrow \\
\mathrm{H}_{2}(\mathrm{~g})+2 \mathrm{CuCl}_{2}(\mathrm{aq})\end{array}$ & $\begin{array}{l}<100 \\
\text { (electrolysis) }\end{array}$ & $\begin{array}{l}\text { Feed: } \\
\text { Output: }\end{array}$ & $\begin{array}{c}\text { Aqueous } \mathrm{CuCl} \text { and } \mathrm{HCl}+\mathrm{V}+\mathrm{Q} \\
\left(55 \mathrm{~kJ} / \mathrm{molH}_{2}\right) \\
\mathrm{H}_{2}+\mathrm{CuCl}_{2} \text { (aq) }\end{array}$ \\
\hline 2 & $\mathrm{CuCl}_{2}(\mathrm{aq}) \rightarrow \mathrm{CuCl}_{2}(\mathrm{~s})$ & $<100$ & $\begin{array}{l}\text { Feed: } \\
\text { Output: }\end{array}$ & $\begin{array}{l}\text { Slurry containing } \mathrm{HCl} \text { and } \mathrm{CuCl}_{2}+\mathrm{Q} \\
\qquad\left(33.2 \mathrm{~kJ} / \mathrm{molH}_{2}\right) \\
\text { Granular } \mathrm{CuCl}_{2}+\mathrm{H}_{2} \mathrm{O} / \mathrm{HCl} \text { vapours }\end{array}$ \\
\hline 3 & $\begin{array}{l}2 \mathrm{CuCl}_{2}(\mathrm{~s})+\mathrm{H}_{2} \mathrm{O}(\mathrm{g}) \rightarrow \\
\mathrm{Cu}_{2} \mathrm{OCl}_{2}(\mathrm{~s})+2 \mathrm{HCl}(\mathrm{g})\end{array}$ & 400 & $\begin{array}{l}\text { Feed: } \\
\text { Output: }\end{array}$ & $\begin{array}{l}\text { Powder/granular } \mathrm{CuCl}_{2}+\mathrm{H}_{2} \mathrm{O}(\mathrm{g})+\mathrm{Q} \\
\qquad\left(120.2 \mathrm{~kJ} / \mathrm{molH}_{2}\right) \\
\text { Powder/granular } \mathrm{Cu}_{2} \mathrm{OCl}_{2}+2 \mathrm{HCl}(\mathrm{g})\end{array}$ \\
\hline 4 & $\begin{array}{c}\mathrm{Cu}_{2} \mathrm{OCl}_{2}(\mathrm{~s}) \rightarrow 2 \mathrm{CuCl}(\mathrm{l})+1 / 2 \\
\mathrm{O}_{2}(\mathrm{~g})\end{array}$ & 500 & $\begin{array}{l}\text { Feed: } \\
\text { Output: }\end{array}$ & $\begin{array}{c}\text { Powder/granular } \mathrm{Cu}_{2} \mathrm{OCl}_{2}(\mathrm{~s})+\mathrm{Q} \\
\left(125.5 \mathrm{~kJ} / \mathrm{molH}_{2}\right) \\
\text { Molten CuCl salt + oxygen }\end{array}$ \\
\hline
\end{tabular}

Table 1: Steps and chemical reactions in the $\mathrm{Cu}-\mathrm{Cl}$ cycle 


\begin{tabular}{|l|c|}
\hline Property & Value \\
\hline $\begin{array}{l}\text { Inlet temperature oxygen } \\
\text { reactor }\end{array}$ & $550^{\circ} \mathrm{C}$ \\
\hline Flue gas temperature & $340^{\circ} \mathrm{C}$ \\
\hline $\begin{array}{l}\text { Lower heating value of } \\
\text { hydrogen }\left(L H V_{H 2}\right)\end{array}$ & $241.83 \mathrm{~kJ} / \mathrm{mol}$ \\
\hline $\begin{array}{l}\text { Mass flow rate of flue gas } \\
\text { Decomposition pressure }\end{array}$ & $4.72 \mathrm{bar}$ \\
\hline $\begin{array}{l}\text { Exit temperature of oxygen } \\
\text { reactor }\end{array}$ & $450^{\circ} \mathrm{C}$ \\
\hline
\end{tabular}

Table 2: Simulation parameters for chemical heat pump

\begin{tabular}{|l|c|}
\hline & Coefficient of performance \\
\hline Naterer [19] & 4.75 \\
\hline Sharonov et al. [20] & 4.75 \\
\hline Present model & 4.49 \\
\hline
\end{tabular}

Table 3: Comparison of past studies for a decomposition pressure of 4.07bar, mass flow rate of flue gas $5.2 \mathrm{~kg} / \mathrm{s}$, and flue gas temperature of $340^{\circ} \mathrm{C}$ 


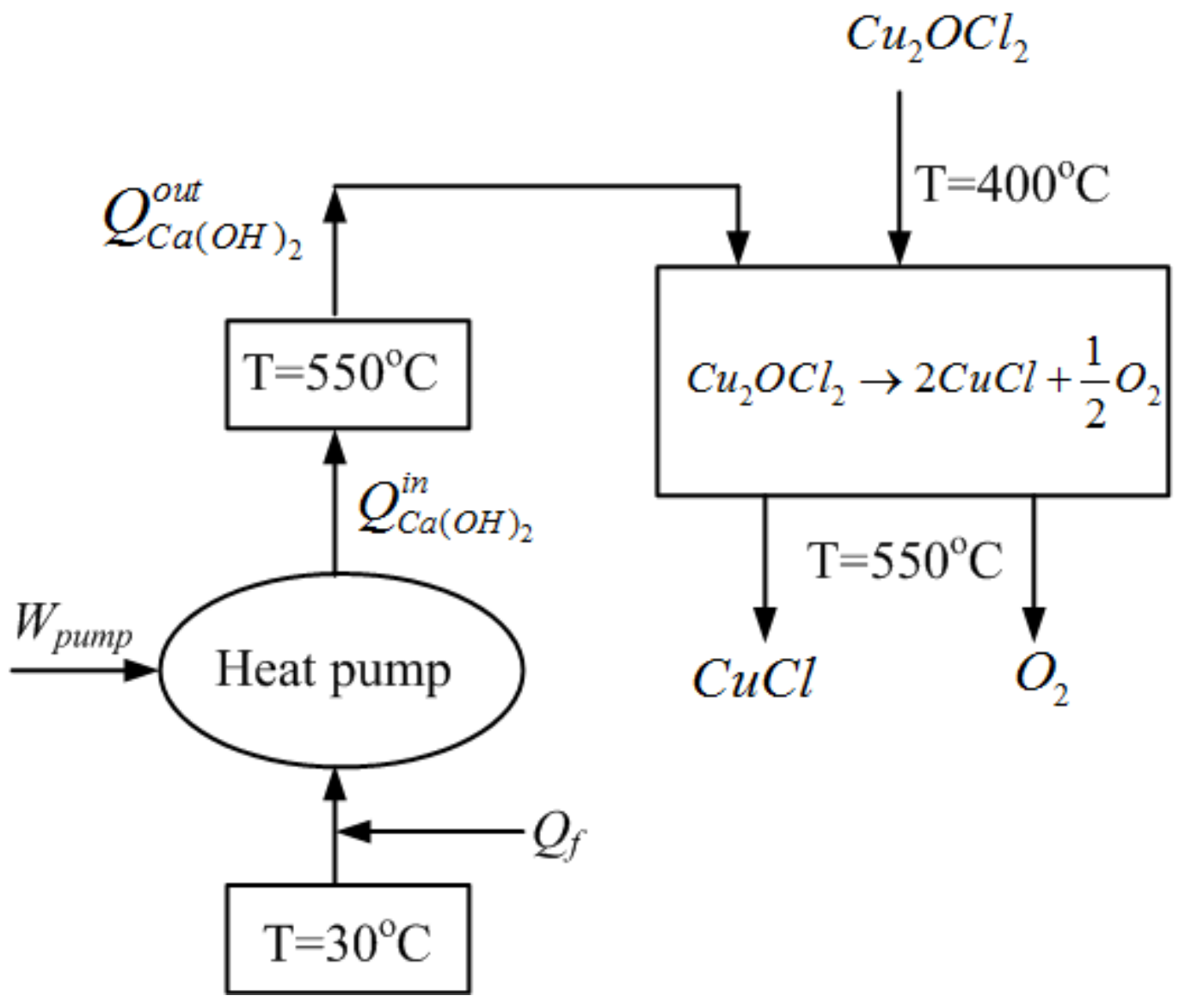

Fig. 1: Schematic of combined CHP and $\mathrm{Cu}-\mathrm{Cl}$ cycle 


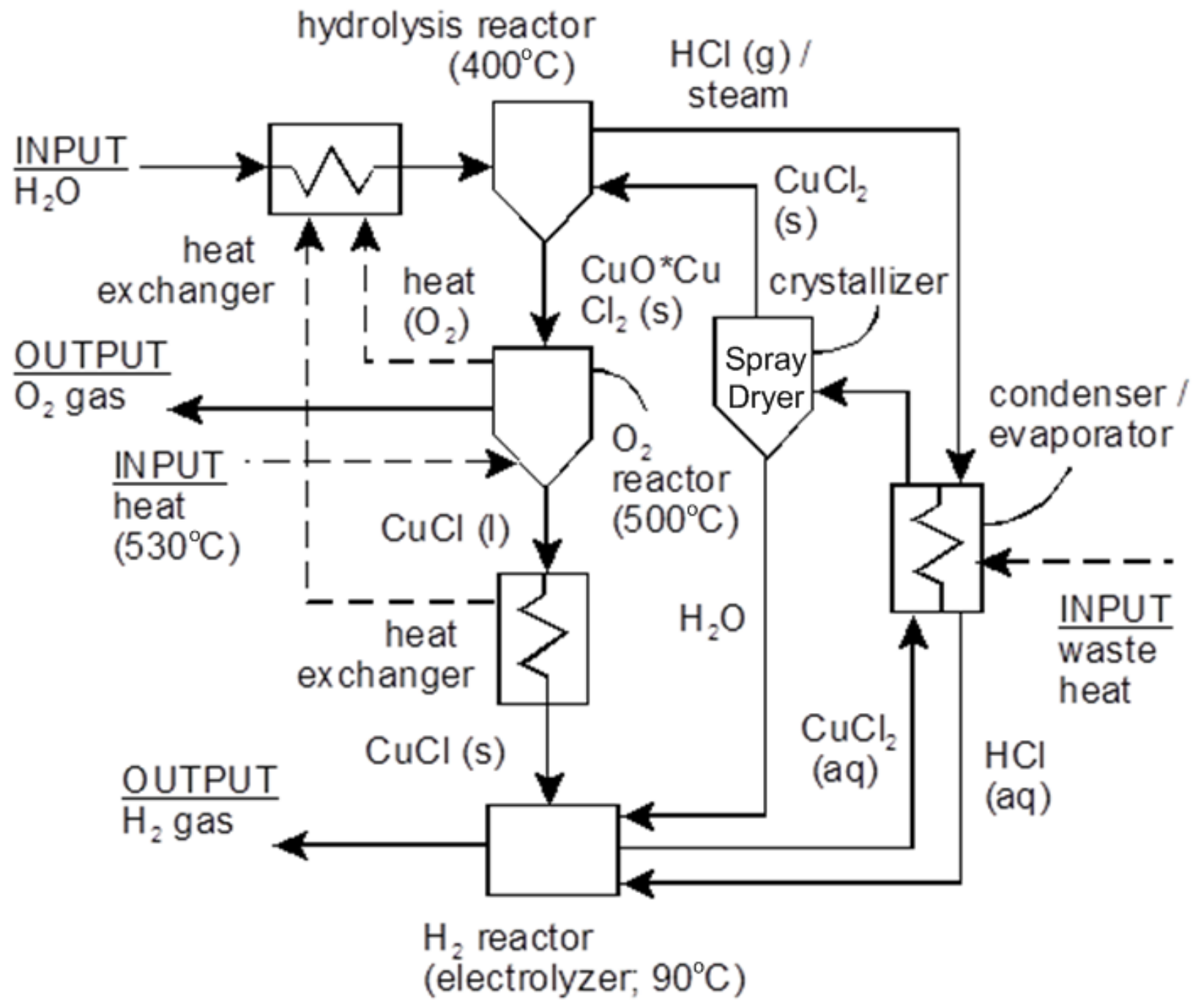

Fig. 2: Schematic of the copper-chlorine ( $\mathrm{Cu}-\mathrm{Cl})$ cycle 


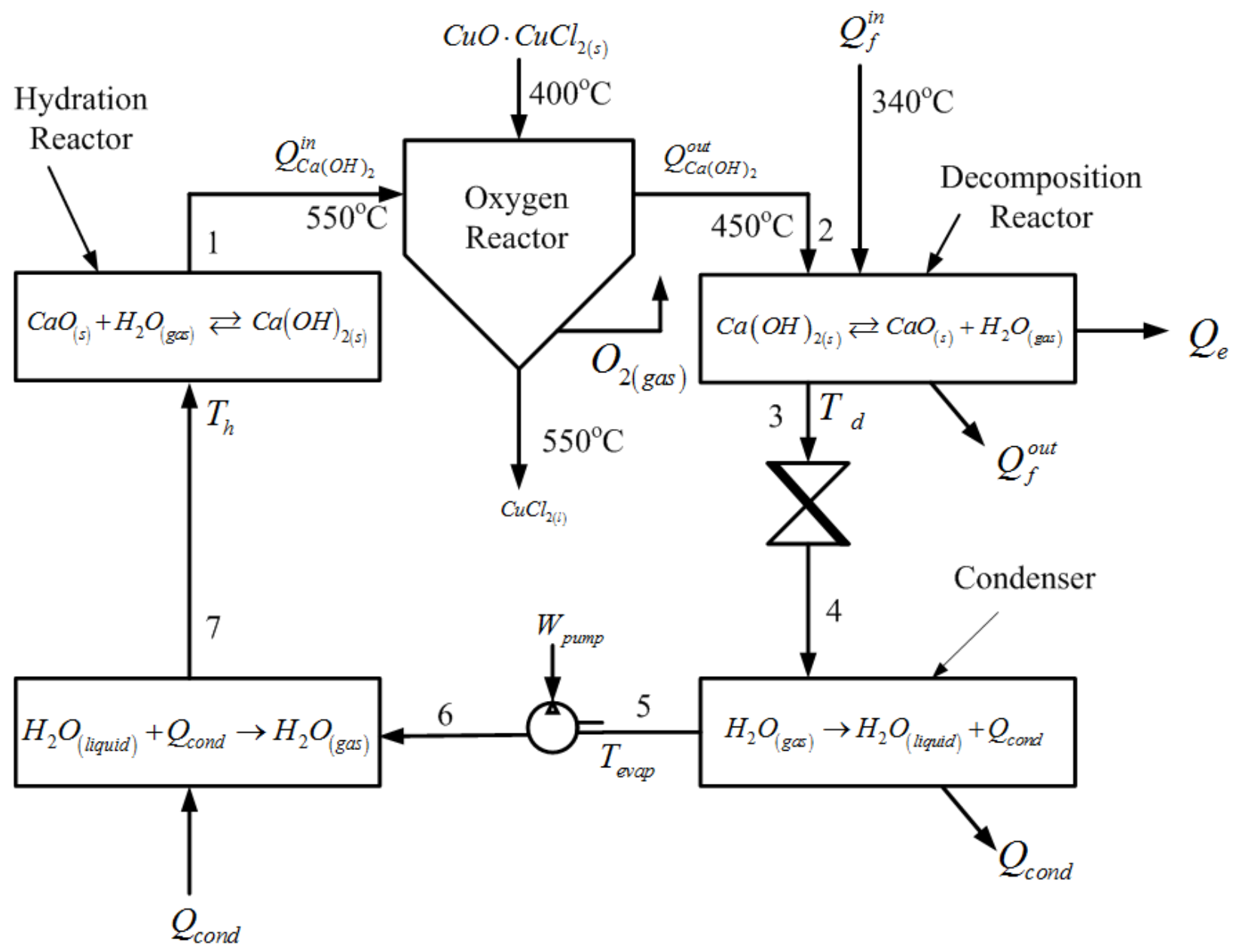

Fig. 3: Schematic of chemical heat pump for heat upgrading to the oxygen decomposition reactor. 


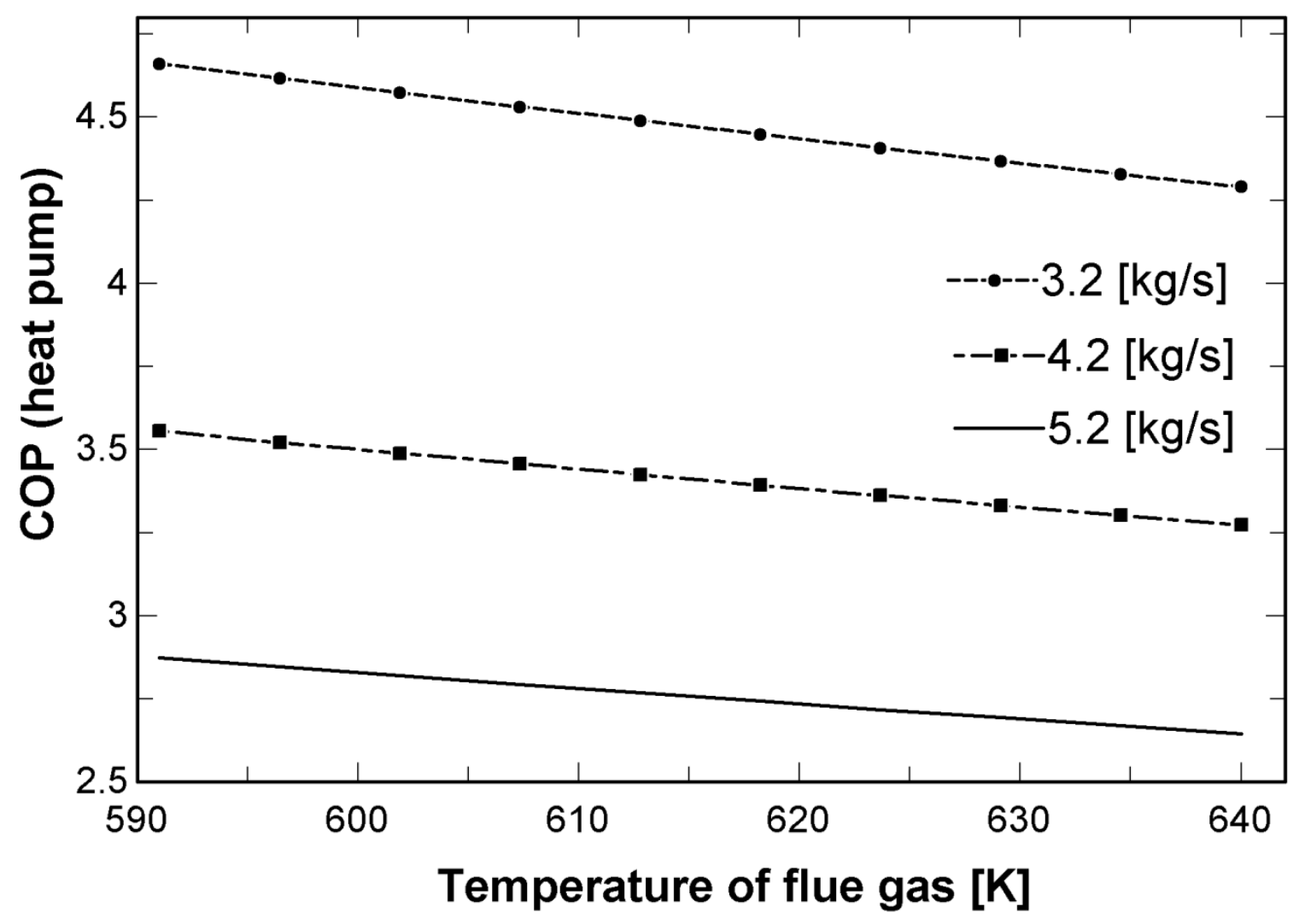

Fig. 4: Effect of varying flue gas temperature of $\mathrm{CHP} / \mathrm{Cu}-\mathrm{Cl}$ cycle for various flow rates of flue gas at $340^{\circ} \mathrm{C}$ with an inlet temperature to the $\mathrm{Cu}-\mathrm{Cl}$ cycle of $550^{\circ} \mathrm{C}$. 


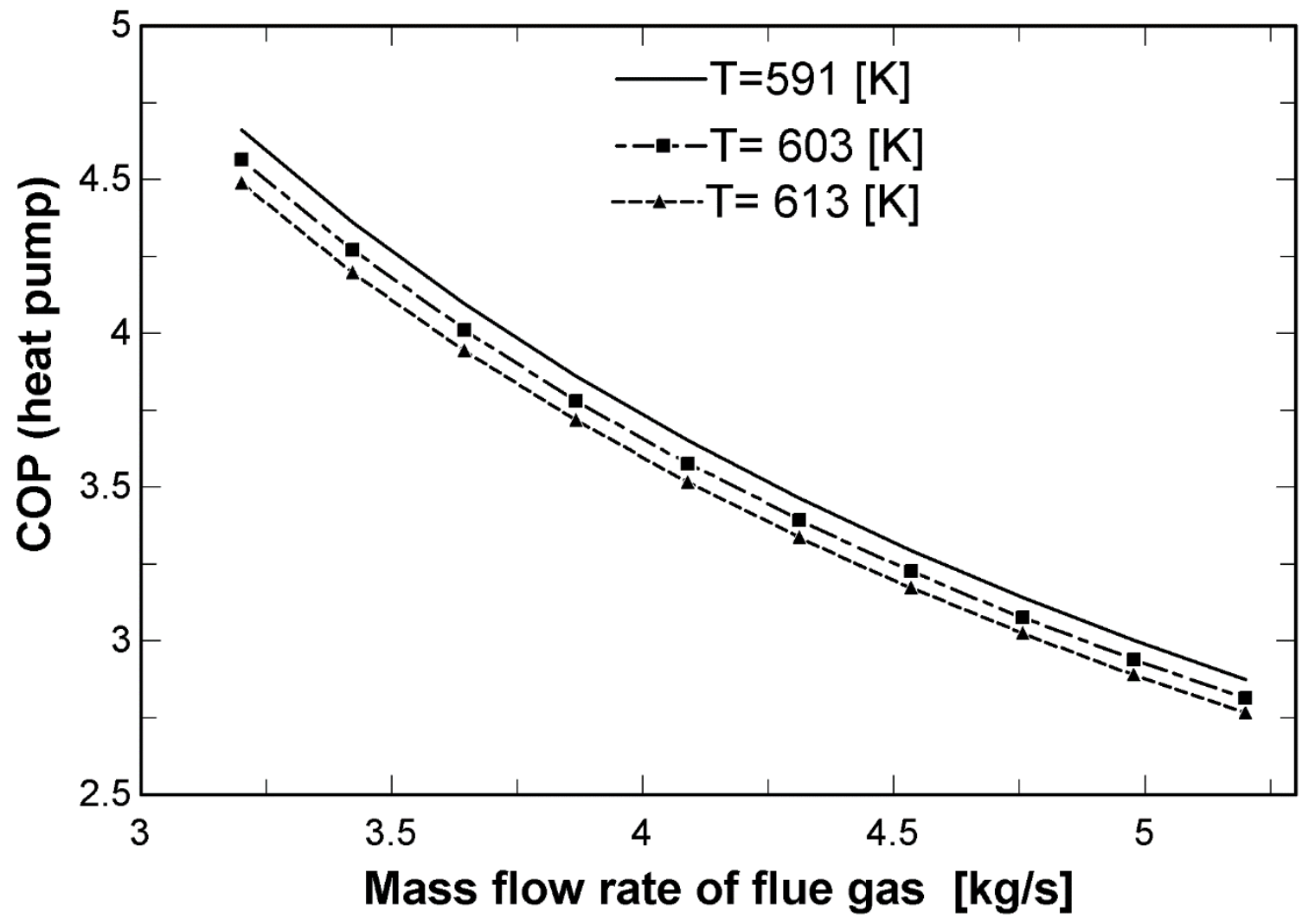

Fig. 5: Effects of varying mass flow rate on COP for different flue gas temperatures and CHP with an inlet temperature to the $\mathrm{Cu}-\mathrm{Cl}$ cycle of $550^{\circ} \mathrm{C}$. 


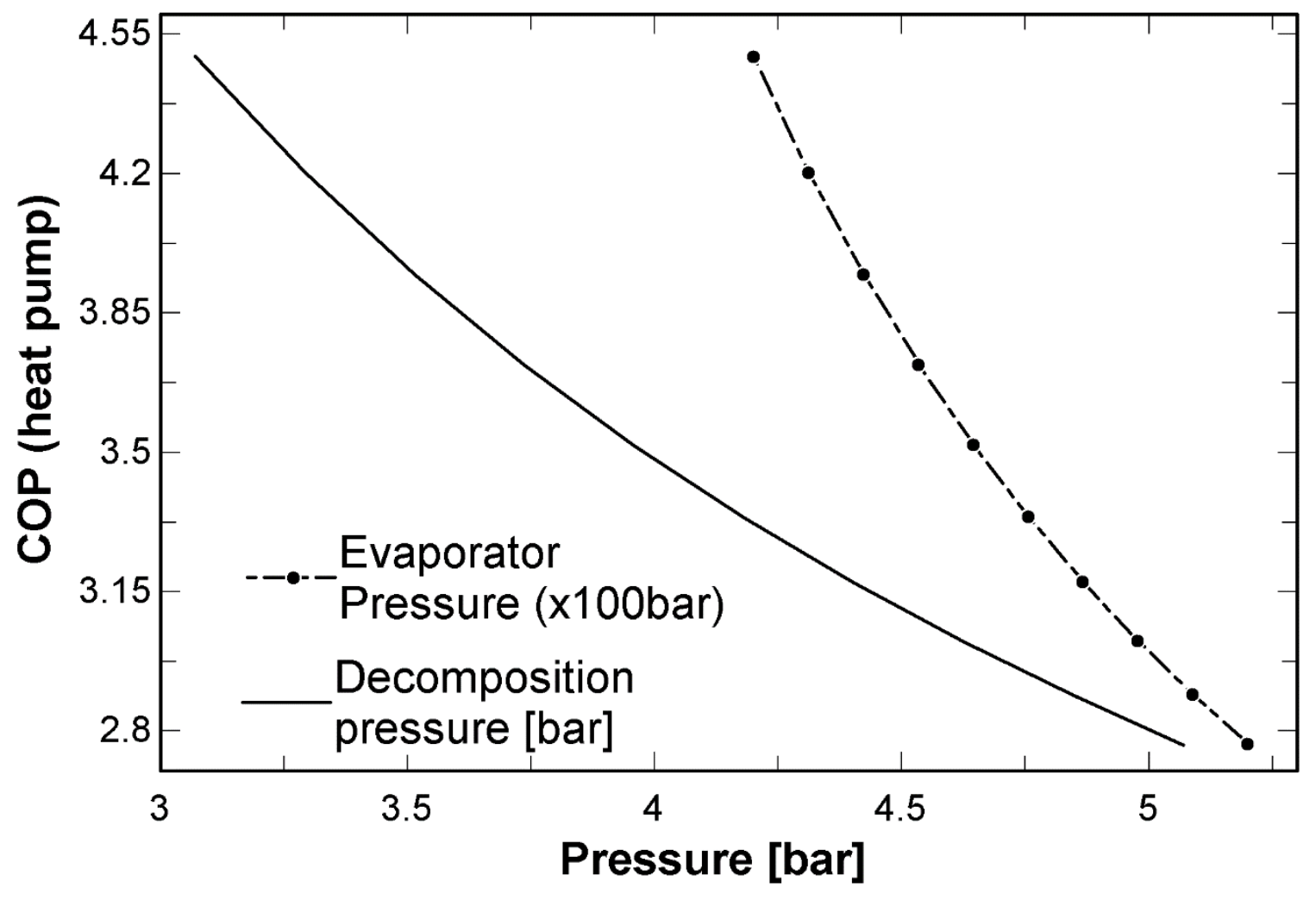

Fig. 6: Effects of evaporator pressure and decomposition pressure on the COP of the CHP with an inlet temperature to the $\mathrm{Cu}-\mathrm{Cl}$ cycle of $550^{\circ} \mathrm{C}$. 


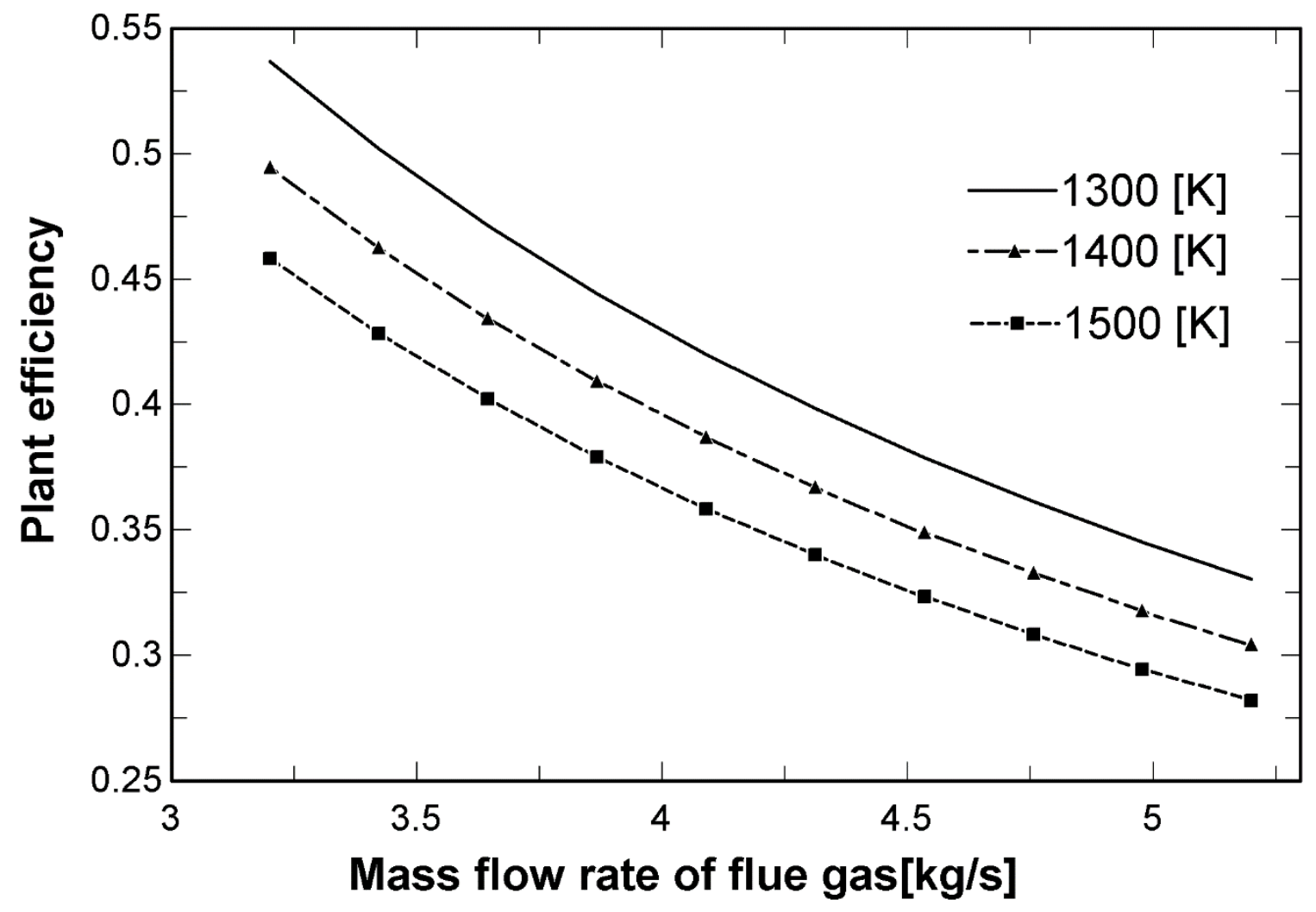

Fig. 7: Effects of varying mass flow rate on plant efficiency when using high temperature flue gas from the clinker to produce hydrogen directly from the $\mathrm{Cu}-\mathrm{Cl}$ Cycle at $550^{\circ} \mathrm{C}$. 


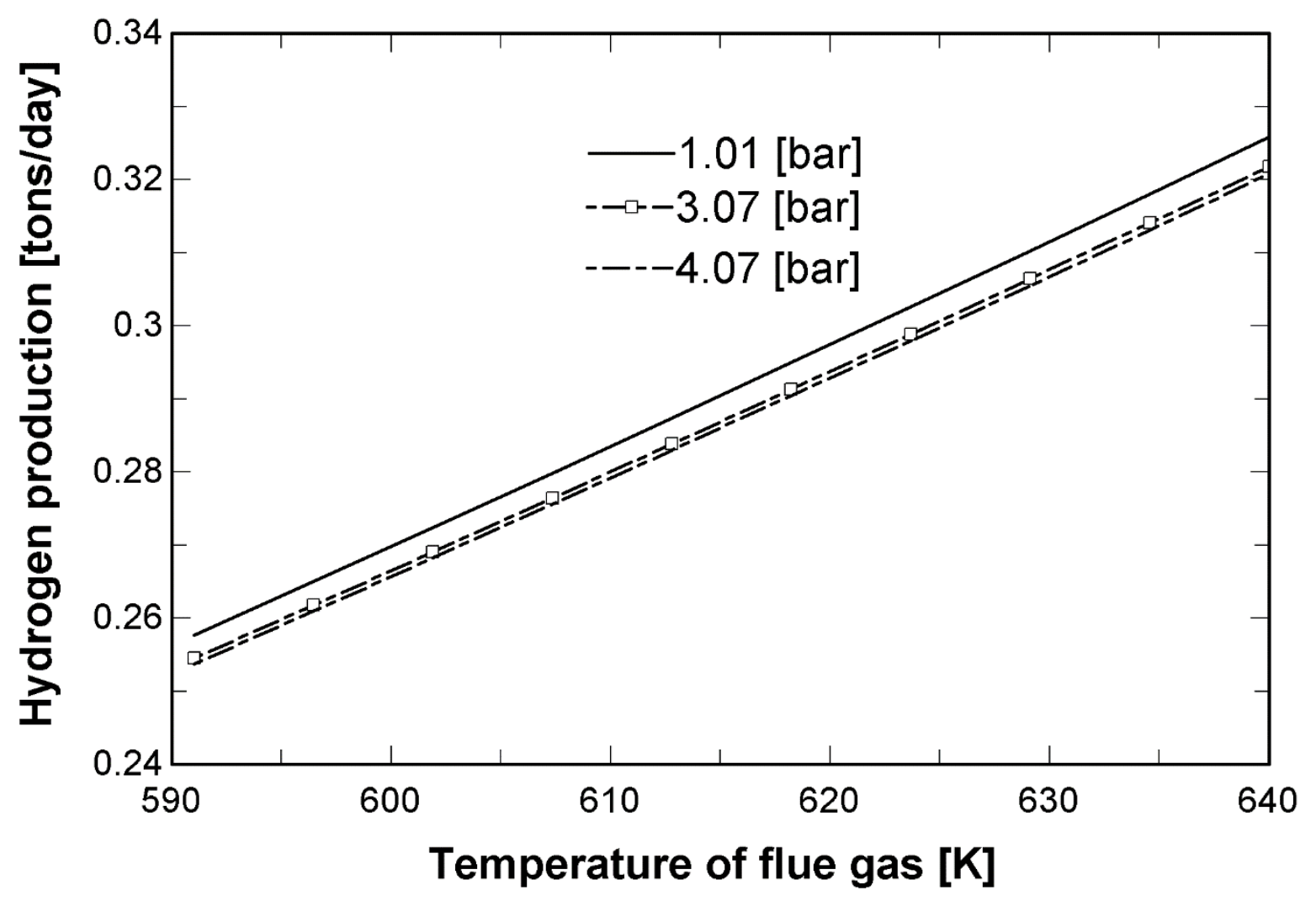

Fig. 8: Hydrogen production using water electrolysis with electricity supplied from steam cycle with mass flow rate of flue gas at 600tons/day. 


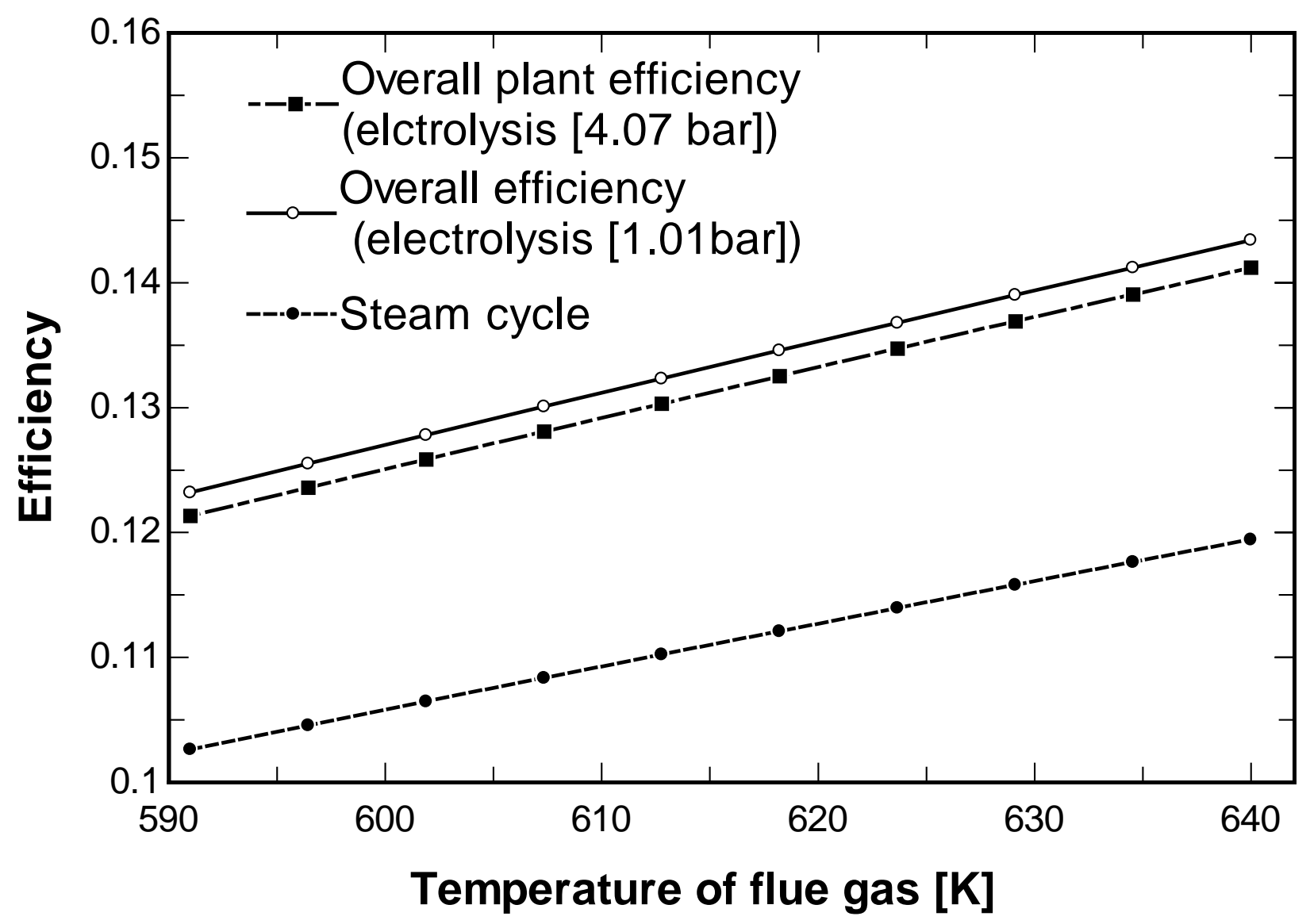

Fig. 9: Efficiency of steam cycle plant and electrolysis of water at different pressures for a fixed mass flow rate of flue gas of $5.2 \mathrm{~kg} / \mathrm{s}$. 


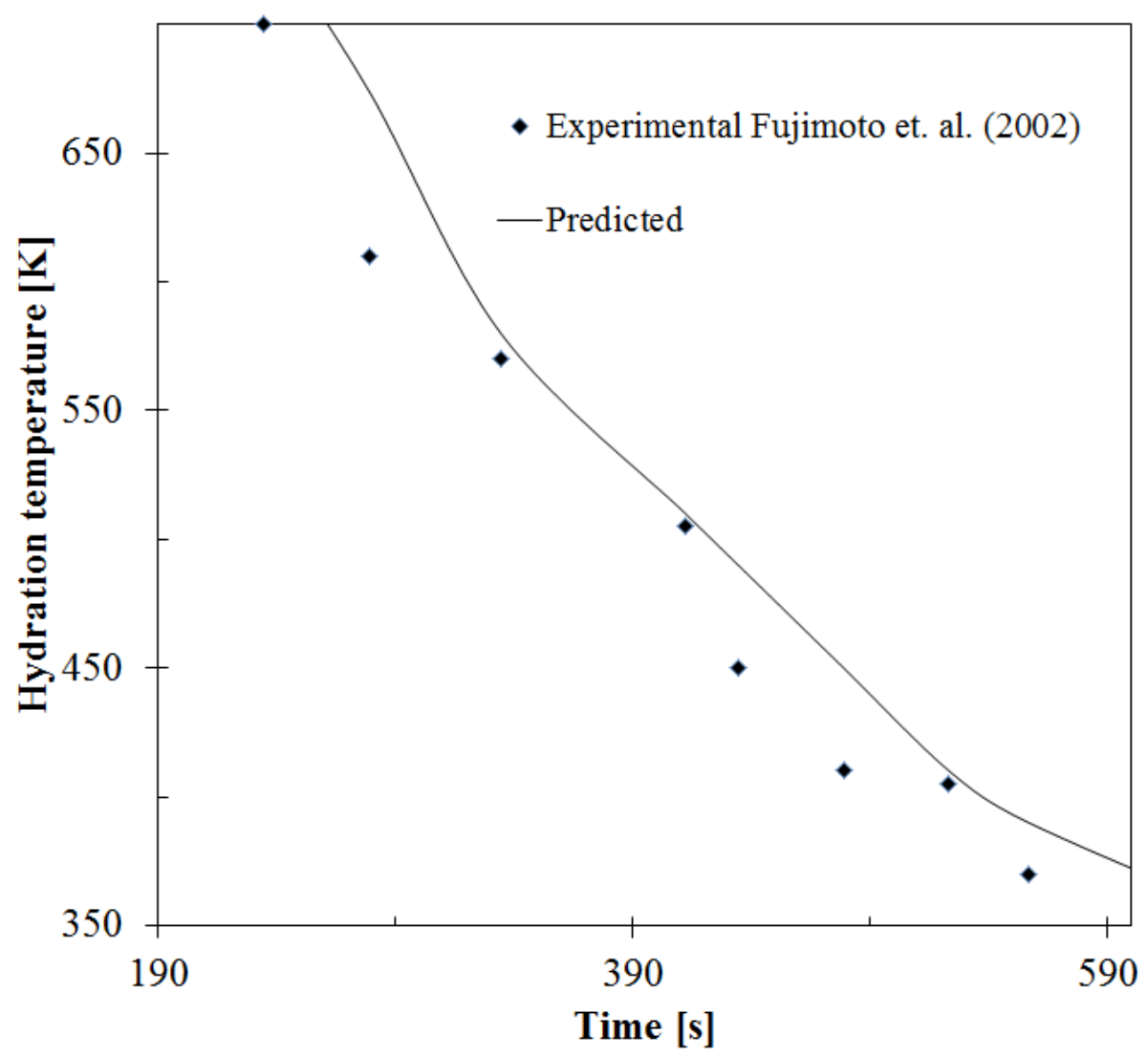

Fig.1: Comparison of experimental and numerical prediction of hydration temperature distribution 